Exposition

\title{
$\mathrm{TiO}_{2}$ photocatalyst for water treatment 酸化チタン光触媒による水処理
}

\section{Akira FUJISHIMA}

Department of Applied Chemistry, Faculty of Engineering. The University of Tokyo, 7-3-1 Hongo, Bunkyo-ku, Tokyo, 113 JAPAN

TEL : 81-3-3812-2111 (EX.7245) FAX:81-3-3812-6227 e-mail :akira-fu@fchem.t.u-tokyo.ac.jp

\section{Shinoka FUJITA}

Department of Human Development, School of Humanities and Culture, Tokai University, 1117 Kitakaname, Hiratsuka, Kanagawa, 259-12 JAPAN

TEL : 81-463-58-1211 (EX.3410) FAX: 81-463-35-2456

( Received 15, April 1997 Accepted 7, August 1997)

Oxidation of contaminants in air and water was achieved by immobilized photocatalysts irradiated with lou-intensity UV light which is inexpensive and poses less human health risk. Tiles and glass coated by $\mathrm{TiO}_{2}$, which are applicable as building materials, have the ability to kill $\mathrm{E}$. coli and other bacteria and to break down foul odor, stains, endotoxin of $\mathrm{E}$. coli under irradiation at low intensity. Photocatalytic oxidation of 3-chlorophenol was also achieved using a ceramic honeycomb coated with $\mathrm{TiO}_{2}$ powder in the circulated flow system under the irradiation at the intensity of $1.7 \mathrm{~mW} / \mathrm{cm}^{2}$ at $360 \mathrm{~nm}$ of light wavelength.

Keywords : Photocatalyst, $\mathrm{TiO}_{2}$, Environmental purification, Water treatment

\section{INTRODUCTION}

光例煤という用翋は一般に、光励起を受けて你 媒作用を示証物資を総称して用いられる。光虫媒 材料住、クロロフィルに代表される金属錯体と半 筧体に大別される。半導体光你煤のなかでも酸化 物半導体は、光励起時に生成する光電荷（価電子 带の正孔および伝尊带の電子）のエネルギーの大 きさや取り报いの容易さもあり、精力的に研究が 進められている。

ここでは、その中でも最も広く用いられている 酸化テタンを例に、その特徵や応用研究の展望な どについて述べる。

\section{CHARACTERISTICS OF $\mathrm{TiO}_{2}$ PHOTOCATALYST}

酸化チタンを用いる光触媒反応の特徵としては、 次の3点を挙げることができる。（Fig. 1）一つ は、励起電子のもつ還元力よりも、正孔のもつ酸 化力が非常に強いことである。そのため、有機化 合物や窒素酸化物などさまざまなものを酸化分解 することができる。水処理に用いられている塩素 やオゾンと比較しても、酸化チタンの方が強力な
酸化力をもつ。（Fig. 2）

二つめの特徵は、この反応が酸化チタンの表面 で起こることである。酸化チタンが光励起される と光電荷としての電子と正孔の対が生成し、これ らと酸化チタン上に存在する物質とが酸化還元反

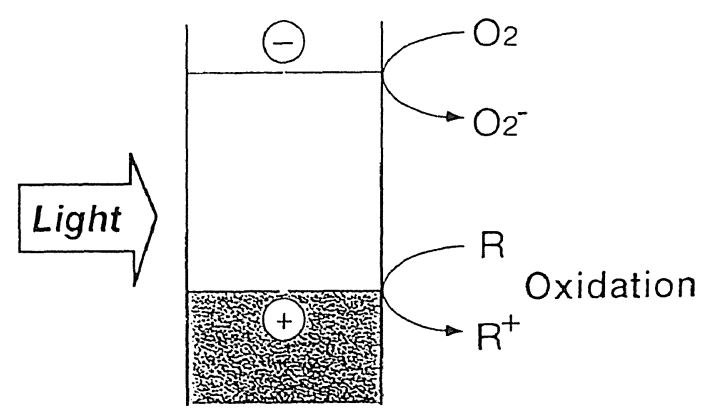

1 Surface Reaction $\longleftrightarrow$ Active Carbon

$\begin{aligned} 21 \text { Strong Oxidation } \underset{\mathrm{NHE}}{\rightleftarrows} & \underset{\text { Ozone }}{\longrightarrow}\end{aligned}$

3 Photochemical Reaction ( UV light)

FIG.1. Characteristics of $\mathrm{TiO} 2$ photocatalyst system. 


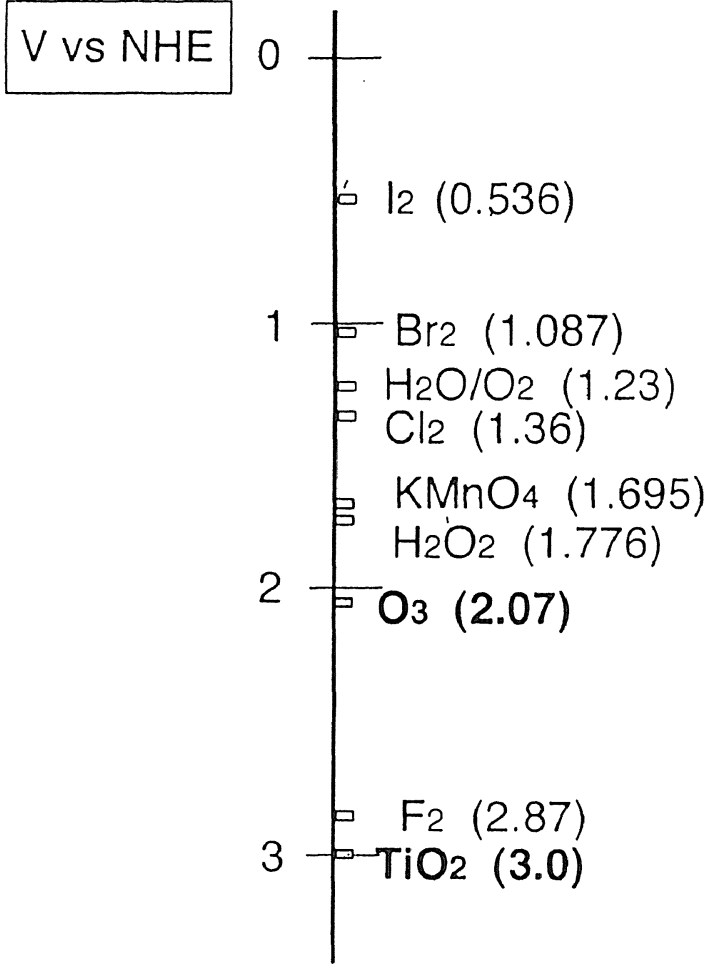

FIG.2. Strong oxidation power.

応を引き起こすが、この時、酸化チタン自身は酸 化も還元もされず、いわゆる触媒の役割に徹する。 そのため、酸化チタンの光触媒能は、半永久的に 持続する。

三つめの特徵は、酸化チタンのバンドギャップ は約 $3 \mathrm{eV}$ であり波長にすると約 $400 \mathrm{~nm}$ 、すなわち $400 \mathrm{~nm}$ 以下の紫外光を照射することによって光化 学反応が進行することである。言い換えれば、酸 化チタン光触媒は可視光には反応しない。

光触媒反応の応用を考えていく上では、これら の特徵を把握し、利点として引き出すことが重要 である。

\section{PURIFICATION OF LIVING SPACE}

光触媒反応の原理にあるのは、ホンダ・フジシ 又効果と呼ばれる水の光分解反応である。 ${ }^{1.2}$ 水 を分解すると水素之酸素が生成することから、こ の効果が発見された当初は水素エネルギーを獲得 する手段として注目された。また、有機化合物の 新しい合成系として利用しようとする研究も行わ れてきた。しかし現在では、酸化チタン光触媒の もつ強力な酸化力に着目して、環境浄化に応用し

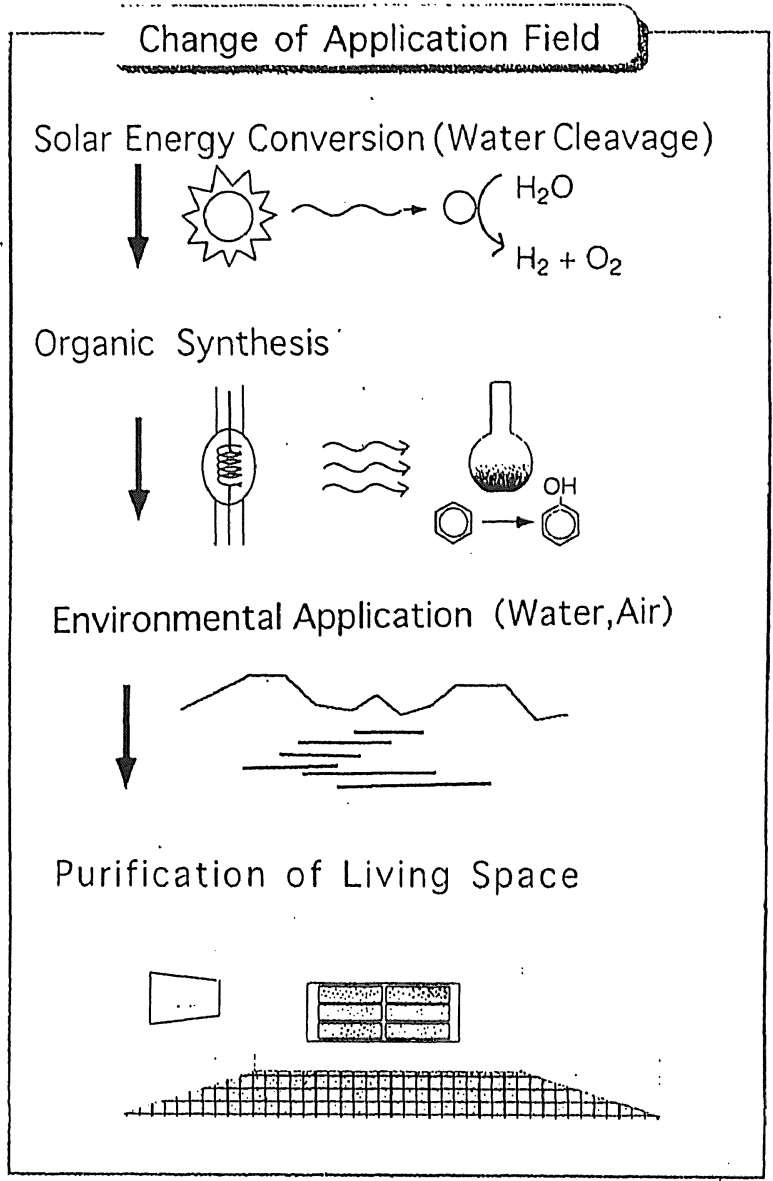

FIG.3. Application of Honda-Fujishima effect.

ようとする研究が盛んになっている。（Fig. 3）

光触媒による環境净化の中にも、対像となる環 境污染物質の濃度や総量、および照射する光の強 度により様々な領域が存在する。タンカー事故な ぞで海上に流出した大量の原油を太陽光を用いて 光触媒で分解しようという研究も行われている。 一方、我々は室内光ほどの微弱な光でも、大気中 の悪臭物質のような低濃度のものを分解するには 有效であることを突き止め応用研究を進めている。 光触媒の研究が始められた当初は、光触媒粉末 を水中に㲘濁して使う系が使われていたが、酸化 チタンの微粒子の分離が必要であるなど取り扱い が難しいことから、酸化チタンの薄層を表面に固 定するなどいくつかの担持系が考案されている。 我々は、各種基板（ガラス、タイル、アルミナな ぞ）のうえにゾル-ゲル法、あるいはディップコー ティング 法などによって 酸化チタン薄膜を厚さ $1 \mu \mathrm{m}$ 程度で形成する方法を開発した。ガラスに 


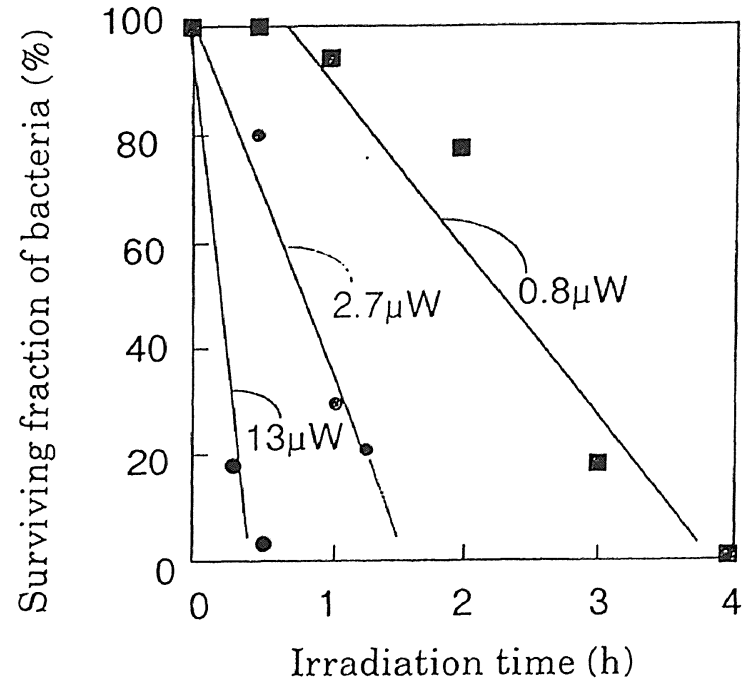

FIG.4. Sterilization effect of photocatalytic tile.

ついてはほぼ透明にコーティングすることに成功 している。

酸化于タン薄膜を建築材料の表面にコートする ことによって、室内外の壁面の污れや、室内の悪 臭物質、さらには空中に浮遊する病原菌などを、 酸化分解できることが明らかになってきた。 Figure 4 には一例として光触媒タイルの殺菌効果 を示した。酸化チタン光促媒を利用した生活空閒 の浄化としては、すでにタイルや照明器具、空気 清浄機などで垁用化され始めた。現在、さらに多 様な分野で製品開発が進められている。

\section{WATER TREATMENT USING TiO2 PHOTOCATALYST}

上述の実用例からも明らかなように、光触媒反 応を活用するためには、酸化チタンの担持方法が ひとつのポイントとなってくる。光蚛媒反応を利 用して水中の污染物質を除去する研究においても、 粕濁系ではたとえ有害物質を除去することができ たとしても、後処理として酸化チタンを取り除か なければならない。そのため、光触媒による水の 浄化を害用化するためには、酸化チタンをなんら かの方法で固定して、酸化チタンと溶媒の分離を 必要としない光反応器を使用することが望ましい。

さまざまなタイプの光反応器が考案されている が、 ${ }^{3 \sim 5}$ そのほとんどはまだ実験室規模のもの である。実用化に向けて、反応効率やランニング コストなどいろいろな面でスケールアップする必 要がある。

\section{Water Purification by \\ Photocatalysis}

Sewage Industrial and AgriculturalWastewater

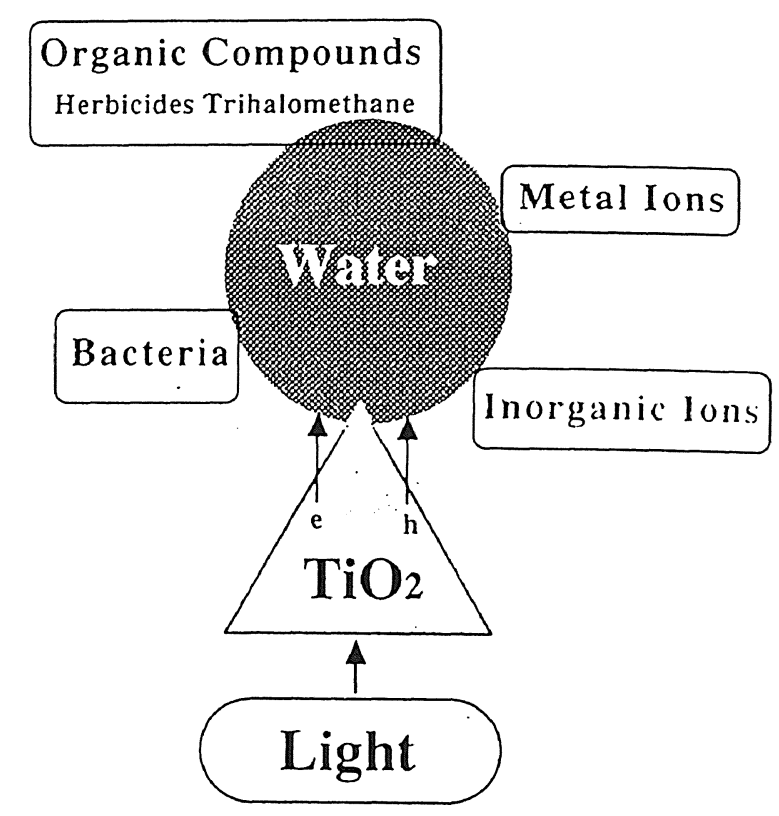

FIG.5. Water purification by photocatalysis.

また、光触媒反応により励起された電子の反応 相手は主に溶液中に溶け込んでいる酸素である。 そのため、污染水を循環させて净化する場合には、 空気を自動的に補給する装置を付ける必要がある。 水処理を必要とする領域は、上下水道から、工 場排水、農業排水、さらにはプールや貯水タンク の処理など実に多岐にわたっている。（Fig. 5）

例えば我々は、周辺住民の環境に配慮して製鉄 所·発電所の冷却水を清净化するために光触媒が 使えないかと相談を受けたことがある。同じよう にダムや湖沼、河川の水を净化しようとの提案も あるが、光触媒による分解反応をはるかに上回る 速度で装置に苔が付着してしまうなどの問題があ り実用化には至っていない。

また、温泉や24時間風呂の湯の浄化に関して相 談を受けたこともある。24時間風呂については、 最近になってレジオネラ菌が発見されるなど、そ のシステム自体が問題となってしまっているが、 光触媒の利用に関しても、湯の中で $\mathrm{Ca}^{2+}$ と $\mathrm{CO}_{2}$ が 反応して $\mathrm{CaCO}_{3}$ が析出し、酸化チタンの表面を覆つ てしまう点などが指摘されている。実用化に際し 
ては、安全性も含めて慎重に検討する必要がある ことを痛感させられる例である。

上水道の浄化についても期待が寄せられている。 水道の蛇口のような流水に応用するのは難しいと 思われるが、貯水タンクの水を循環させながら浄 化することは可能ではないかと考えている。

そこで、粉末酸化チタンをコートしたセラミッ クハニカム（ST-H01、石原産業製）を用いた水 の浄化実験結果の一部を紹介する。 ${ }^{6}$ 八二カム 形状は大きな触媒表面積を有し、水処理システム に多用されているフロー系に適していると考えら れる。1.18mM03-クロロフェノール(3CP) 水溶液 600mLをFig.6に示すようなサーキュレイトフロー システムを用い、ブラックライトを照射 $\left(1.7 \mathrm{~mW} / \mathrm{cm}^{2}\right)$ しながら流速6.0 $\mathrm{mLcm}^{-2} \mathrm{~min}^{-1}$ で24時間 循環させたところ、Fig.7に示すように、32\%の $3 \mathrm{CP}$ が分解、また $3 \mathrm{CP}$ の初濃度の $10 \%$ がCO2にま で完全に分解された。なお、使用したハニカムの サイズは $3.7 \mathrm{~cm} \times 10.6 \mathrm{~cm} \times$ 厚さ $1.2 \mathrm{~cm}$ であり、実質 の接触反応時間は循環時間24時間のうちわずか 38minである。この間、384回循環していることに なる。この結果から計算される一回の循環で変化 する $3 \mathrm{CP}$ と $\mathrm{CO}_{2}$ の量は $4.44 \times 10^{-1} \mathrm{mmol}$ と $8.93 \times$ $10^{1} \mathrm{mmol}$ と小なものである。したがって、ハニ カムとブラックライトを交互にしたカラム装置を 用いる必要はあるが、このような方式での水の浄 化は可能であると考える。

black light $(1.7 \mathrm{~mW} / \mathrm{cm} 2)$

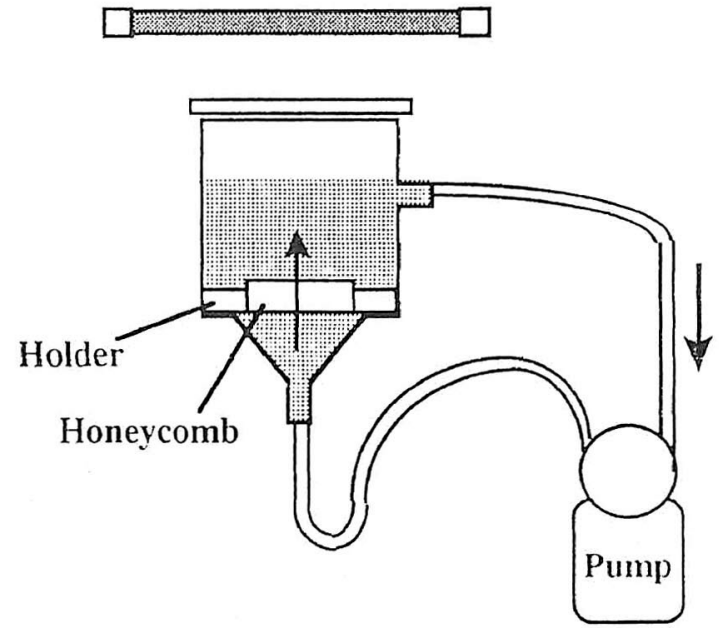

FIG.6. Gas-tight recirculating system using $\mathrm{TiO}_{2}$ coated honeycomb ceramics.

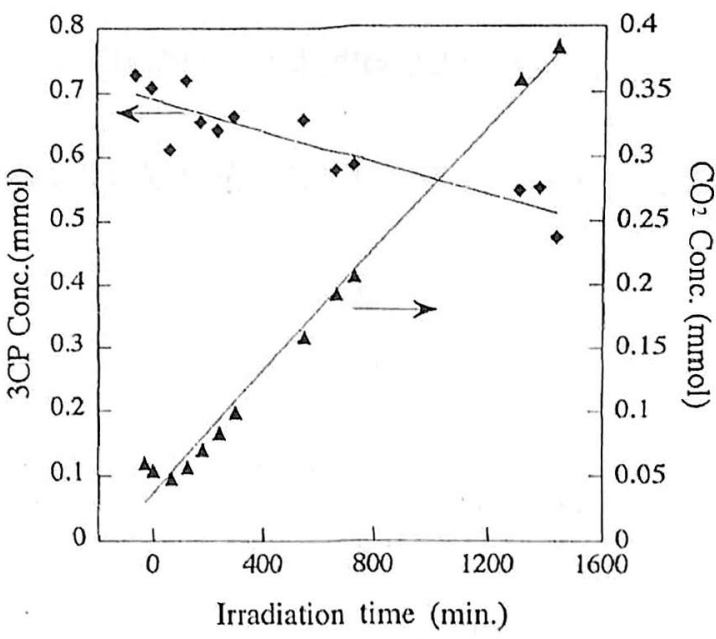

FIG.7. Photocatalytic degeneration of 3-chlorophenol and $\mathrm{CO}_{2}$ production.

\section{CONCLUSION}

光触媒の水処理への応用に凬して現在われわれ が抱いているイメージは、大量の污水を処理する ようなものではなく、わずかの润れがあるところ を完全に浄化して迢純水をつくるような場洏であ る。生活空間の浄化への応用としてすでに奏用化 が始まっている光虫媒タイルでは、空気小の浮旅 菌数を澈減させたり、室内のペット卓などを抑例 する效果も明らかになっており、次はぜひ水处理 領域で、光促媒が活踓することを期待したい。

\section{REFERENCES}

'A.Fujishima and K.Honda. Bull. Chem. Soc. Japan, 44 (4), 1148 (1971)

${ }^{2}$ A.Fujishima and K.Honda, Nature, 238, 37 (1972)

${ }^{3}$ R.W.Matthews, J.Phys.Chem., 91, 3328 (1987)

${ }^{4}$ N.Z.Murado, Solar Energy, 52, 283 (1994)

${ }^{5}$ Y.Zhang, J.C.Crittenden, D.W.Hand, D.L.Perram, Environ. Sci. Technol., 28, 435 (1994)

${ }^{6}$ S.Fujita, T.Iyoda, K.Hashimoto, A.Fujishima, Abstracts of Spring Annual Meeting of Chemical Society of Japan, 429 (1996)

著者紹介 藤㑑 詔（ふじしま あきら） 東京大学工学系们究科教授。詔和 46 年

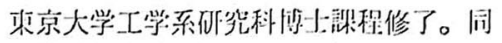
年神奈川大学新们。同 50 年来京大学工:

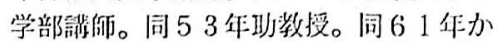
ら教授。工学狩士。 現在の研究分鹏/テーマ

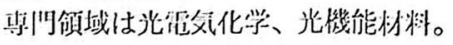
代表的研究は太陽光による水の光分解。 酸化チタン光伿媒による環境游化。

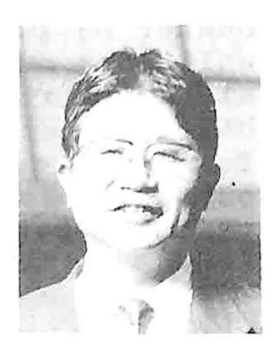

195 